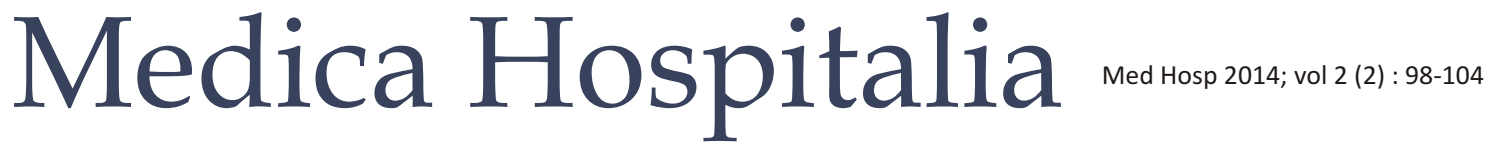

Original Article

\section{Pemberian Vitamin C sebagai Antioksidan terhadap Fragilitas Osmotik Eritrosit pada B Thalassemia Mayor}

\author{
Ricki Rajagukguk, M. Sholeh Kosim, Moedrik Tamam \\ Departemen IKA Fakultas Kedokteran Universitas Diponegoro/RSUP Dr. Kariadi Semarang
}

\begin{abstract}
Abstrak
Latar belakang : Vitamin C berperan sebagai antioksidan untuk melawan peroksidasi membran fosfolipid yang disebabkan oleh stres oksidatif sehingga diharapkan dapat memperbaiki fragilitas osmotic mendekati rentang normal. Pemeriksaan fragilitas osmotik eritrosit dulu sejarahnya dilakukan untuk uji tapis beta thalassemia mayor. Tranfusi darah masih merupakan pengobatan utama untuk menanggulangi anemia pada thalassemia pada saat ini. Pemberian tranfusi berulang menyebabkan penimbunan besi yang berlebihan yang selanjutnya mengakibatkan kerusakan oksidatif. Tujuan penelitian ini untuk membuktikan apakah pemberian vitamin $\mathrm{C}$ dapat memperbaiki fragilitas osmotik eritrosit pada pasien $\beta$ thalassemia.

Metode : Desain penelitian Double blind Randomized Control trial pada pasien $\beta$ thalassemia mayor yang memenuhi criteria inklusi. Subjek diambil dengan cara consecutive sampling dibagi menjadi 2 kelompok. Kelompok I (kelompok perlakuan) diberikan vitamin C sebanyak 100 mg , Kelompok II (kelompok control) diberi plasebo setiap hari selama 1 bulan. Randomisasi perlakuan dilakukan dengan blok alokasi. Fragilitas osmotik eritrosit diperiksa di Instalasi Laboratorium RSUP Dr.Kariadi. Analisis statistik dengan UjiX ${ }^{2}$.

Hasil : Subjek 50 orang; Kelompok I : 25 orang, Kelompok II : 25 orang. Kelompok I didapatkan rerata kadar $\mathrm{Hb}$ sebelum perlakuan $5,81 \pm 1,032$, sesudah perlakuan $6,65 \pm 0,741$, dengan nilai $p=0,000$. Rerata fragilitas osmotik eritrosit sebelum perlakuan $30,75 \pm 5,685$, sesudah perlakuan $38,19 \pm 6,977$, dengan nilai $p=0,000$. Kelompok II didapatkan rerata kadar $\mathrm{Hb}$ sebelum perlakuan $5,84 \pm 1,287$, sesudah perlakuan $5,701 \pm 1,150$, dengan nilai $p=0,591$. Rerata fragilitas osmotik eritrosit sebelum perlakuan $35,25 \pm 7,089$, sesudah perlakuan $29,15 \pm 9,043$, dengan nilai $p=0,004$.

Simpulan : Pemberian vitamin $\mathrm{C}$ dapat memperbaiki fragilitas osmotik eritrosit pada pasien $\beta$ thalassemia selama 1 bulan. Pemberian vitamin $C$ pada pasien $\beta$ thalassemia mayor sebaiknya diberikan lebih dari 1 bulan dengan dosis yang ditambah.
\end{abstract}

Kata kunci : fragilitas osmotik eritrosit, $\beta$ thalassemia mayor, vitamin C

\section{The effect of vitamin C as antioxidant to erythrocyte osmotic fragility in in major $B$ thalassemia}

\begin{abstract}
Background : Vitamin C acts as an antioxidant against membrane phospholipid peroxidation induced by oxidative stress that is expected to improve the osmotic fragility approaching the normal range. Erythrocyte osmotic fragility examination first history of screening tests performed for beta thalassemia major. Blood transfusion is still the primary treatment for overcoming anemia in thalassemia at this time. Giving repeated transfusions cause excessive iron accumulation which in turn lead to oxidative damage. The objective of this study was to determine Vitamin C supplementation could improve the erythrocyte osmotic fragility in major $\beta$ thalassemia patients.

Methods : Design of study was Double blind Randomized Control trial in major $\beta$ thalassemia patients who fulfilled the inclusion criteria. Subjects were taken by consecutive sampling, divided in to 2 groups. Group I (treatment group) was given vitamin C $100 \mathrm{mg}$ daily and Group II (control group) was given placebo daily during 1 month. Randomization of treatment was done by block allocation. Erythrocyte osmotic fragility was examined in Laboratory of Dr. Kariadi Hospital. Statistical analysis used was Chi square test.

Results : Subject were 50 children, consist of Group I : 25 and Group II : 25 children. Group I was found : mean of $\mathrm{Hb}$ level before treatment $5.81 \pm 1.032$, after treatment $6.65 \pm 0.741, p=0.000$. Mean of erythrocyte osmotic fragility before treatment was 30.75 \pm 5.685 , after treatment was $38.19 \pm 6.977, p=0.000$. Group II was found mean $\mathrm{Hb}$ level before treatment $5.84 \pm 1.287$, after treatment $5.701 \pm 1.150, p=0.591$. Mean of erythrocyte osmotic fragility before treatment $35.25 \pm 7.089$, after treatment was $29.15 \pm 9.043$, with $p=0.004$

Conclusion : Vitamin C supplementation during 1 month could improved the erythrocyte osmotic fragility in major $\beta$ thalassemia patients. Vitamin $C$ supplementation may given more longer than 1 month with additional doses.
\end{abstract}

Keywords : erythrocyte osmotic fragility, $\beta$ thalassemia, vitamin C 


\section{PENDAHULUAN}

Salah satu ciri kelainan thalassemia adalah destruksi sel darah merah yang lebih cepat daripada sel darah merah normal. Kelainan sel darah merah pada thalassemia disebabkan oleh gangguan sistesis rantai alfa dan beta pada hemoglobin. ${ }^{1}$ Produksi rantai beta globin pada beta thalassemia mayor menurun dalam jumlah besar. Penurunan produksi beta globin menyebabkan peningkatan jumlah rantai alfa globin yang kemudian menyebabkan kerusakan oksidatif seluler pada pasien thalassemia $B$ mayor. Hal ini kemudian menyebabkan fragilitas osmotik dari sel darah merah rendah dibandingkan sel darah merah normal. Sel darah merah thalassemia lebih resisten terhadap lisis pada larutan hipotonis. Hal ini menunjukkan penurunan dari fragilitas osmotik. ${ }^{2}$ Untuk mempertahankan hidupnya, penderita thalassemia $B$ mayor memerlukan transfusi darah yang teratur. Akan tetapi transfusi darah berulang dapat menimbulkan efek samping berupa penumpukan besi dalam jaringan-jaringan. ${ }^{3}$

Thalassemia $B$ mayor, selain terjadi penumpukan besi intrasel, juga terjadi peningkatan jumlah kompleks besi berberat molekul rendah. ${ }^{4}$ Logam transisi, seperti besi, dalam lingkungan intraseritrosit yang kaya akan oksigen dapat mengakibatkan toksisitas oksigen melalui pembentukan radikal bebas yang dapat merusak berbagai komponen sel antara lain membran. Sel eritrosit memiliki membran sel berlapis ganda yang tersusun atas $50 \%$ lipid dan $50 \%$ protein, oleh karenanya sel membran eritrosit ini rentan terhadap kerusakan yang ditimbulkan oleh radikal bebas. Salah satu produk oksidasi lipid membran adalah malondialdehid (MDA) yang dapat menggambarkan adanya beban oksidatif sehingga diperlukan antioksidan yang tinggi. ${ }^{5}$

Eitan Fibach et al membuktikan bahwa kadar besi bebas secara ekstraselular (labile plasma iron, LPI) dan intraselular (labile iron pool, LIP) banyak diidentifikasi sebagai penyebab stres oksidatif pada sel darah pasien thalassemia dengan cara memacu pembentukan radikal oksigen. Hal ini menjadi dasar dalam pemberian terapi seperti antioksidan dan chelating agent pada penderita thalassemia $ß$ mayor. ${ }^{6}$

Kelebihan besi intrasel dalam jumlah besar dapat berperan sebagai katalis dalam proses peroksidasi lipid membran. Kerusakan peroksidatif protein membran sel darah merah dibuktikan dengan terjadinya ikatan lintas silang pada beberapa protein membran sel darah merah. Kerusakan peroksidatif membran sel darah merah akibat dari aktivitas oksidan tersebut memperburuk fragilitas eritrosit penderita thalassemia. ${ }^{7}$ Antioksidan didefinisikan sebagai senyawa yang dalam jumlah kecil dapat menunda atau menghambat kerusakan oksidatif suatu molekul sasaran. Antioksidan dapat melindungi molekul, sel, dan jaringan sasaran dengan cara memusnahkan Reactive Oxygen Species (ROS) baik secara enzimatik maupun dengan reaksi kimia langsung, mengurangi pembentukan ROS dan mengikat ion-ion logam yang terlibat dalam pembentukan spesies yang reaktif. $^{7}$

Vitamin C sebagai salah satu antioksidan, bekerja sebagai donor elektron, dengan cara memindahkan satu elektron ke senyawa logam Cu. Selain itu, vitamin C juga dapat menyumbangkan elektron ke dalam reaksi biokimia intraseluler dan ekstraseluler. Vitamin C mampu menghilangkan senyawa oksigen reaktif di dalam sel netrofil, monosit, protein lensa, dan retina. Vitamin ini juga dapat bereaksi dengan Fe-ferritin. Diluar sel, vitamin C mampu menghilangkan senyawa oksigen reaktif, mencegah terjadinya LDL teroksidasi, mentransfer elektron ke dalam tokoferol teroksidasi dan mengabsorpsi logam dalam saluran pencernaan. ${ }^{8}$ Konsentrasi vitamin C pada anak dengan stres oksidatif lebih rendah dibandingkan dengan kadar vitamin C pada anak normal. ${ }^{9}$ Menurut McGregor and Biesalski kenaikan kadar plasma vitamin. ${ }^{10}$ Setelah 6 bulan terapi dengan menggunakan beberapa vitamin yang berfungsi sebagai antioksidan, pasien-pasien dengan $ß$ thalassemia menunjukkan peningkatan yang signifikan terhadap beberapa parameter non enzimatik dari aktivitas antioksidan jika dibandingkan dengan sebelum dilakukan perlakuan. Penelitian tersebut menunjukkan bahwa pemberian suplementasi vitamin $C$ memberikan manfaat pada pasien-pasien beta thalassemia. Selain itu penelitian ini juga menyimpulkan bahwa tidak terdapatnya kontraindikasi pada pemberian vitamin c dosis rendah pada pasien-pasien beta thalassemia dengan defisiensi vitamin C. Terdapatnya penurunan MDA yang signifikan setelah pemberian beberapa vitamin dengan fungsi antioksidan. ${ }^{11}$

Pemeriksaan fragilitas osmotik eritrosit satu tabung, sejarahnya dulu digunakan sebagai tes skrining/uji tapis untuk penderita thalassemia $B$ mayor Uji fragilitas osmotik eritrosit dilakukan untuk mengukur kemampuan eritrosit menahan terjadinya hemolisis dalam larutan yang hipotonis. Eritrosit dilarutkan dalam larutan salin dengan berbagai konsentrasi. Jika terjadi hemolisis pada larutan salin yang sedikit hipotonis, keadaan ini dinamakan peningkatan fragilitas eritrosit (=penurunan resistensi/daya tahan eritrosit), dan apabila hemolisis terjadi pada larutan salin yang sangat hipotonis, keadaan ini mengindikasikan penurunan fragilitas osmotik (=peningkatan resistensi eritrosit). ${ }^{12,13}$

Penelitian ini bertujuan untuk membuktikan apakah pemberian vitamin $C$ dapat memperbaiki fragilitas osmotik eritrosit pada pasien thalassemia $B$ mayor sehingga pada akhirnya akan memperbaiki kadar hemoglobin pasien dan menjarangkan frekuensi transfusi. Test fragilitas osmotik eritrosit pada penelitian ini hanya digunakan untuk konfirmasi secara ilmiah bukan untuk uji tapis/skrining. 


\section{METODE}

Desain penelitian menggunakan double blind randomized control trial pada pasien $\beta$ thalassemia mayor yang memenuhi kriteria inklusi : penderita thalassemia mayor yang mendapat transfusi berulang (10-20 kali transfusi), Umur 2-14 tahun, tidak menderita penyakit kelainan hematologi lain, tidak menderita gizi buruk, tidak gagal ginjal, tidak menggunakan suplemen antioksidan atau herbal. Subjek diambil dengan cara consecutive sampling dibagi menjadi 2 kelompok. Randomisasi perlakuan dilakukan dengan blok alokasi. Kelompok I (kelompok perlakuan) diberikan vitamin C sebanyak 2x100 mg/hari, Kelompok II (kelompok kontrol) diberi plasebo dua kali setiap hari selama 1 bulan. Fragilitas osmotik eritrosit diperiksa di Instalasi Laboratorium RSUP Dr. Kariadi Semarang. Analisis statistik dengan Uji $X^{2}$.

\section{HASIL}

Penelitian ini merupakan penelitian eksperimental dengan desain Double blind Randomized Control Trial (RCT) yang melibatkan subjek sebanyak 50 kasus $\beta$ thalassemia mayor yang memenuhi kriteria inklusi. Pengambilan subjek berdasar consecutive sampling, urutan dia datang. Sedangkan perlakuan randomisasi berdasarkan blok alokasi. Kelompok I terdiri dari 25 subjek yang mendapat perlakuan diberi suplementasi vitamin C sebanyak 100mg/perhari, 2 kali perhari selama 1 bulan. Kelompok II terdiri dari 25 subjek yang diberi placebo tiap hari selama 1 bulan. Karakteristik demografis subjek dapat dilihat pada Tabel 1 .
Tabel 1 menunjukkan bahwa di antara 2 kelompok tidak terdapat perbedaan bermakna tentang karakteristik demografis subyek. Sedangkan manifestasi klinis yang biasa ditemukan pada pasien thalassemia mayor, dapat dilihat pada Tabel 2 .

Tabel 3 menunjukkan bahwa terdapat perbedaan yang bermakna tentang kadar $\mathrm{Hb}$, $\mathrm{Ht}$ dan fragilitas osmotic eritrosit pada Kelompok I sebelum dan sesudah perlakuan yaitu sesudah pemberian vitamin $C$ selama 1 bulan.

Tabel 4 menunjukkan bahwa bahwa tidak terdapat perbedaan yang bermakna tentang kadar $\mathrm{Hb}, \mathrm{Ht}$ dan fragilitas osmotic eritrosit pada Kelompok II sebelum dan sesudah perlakuan yaitu sesudah pemberian vitamin C selama 1 bulan.

Tabel 5 menunjukkan bahwa delta (selisih) kadar $\mathrm{Hb}, \mathrm{Ht}$ dan Fragilitas osmotik kedua kelompok berbeda secara bermakna.

Tabel 6 menunjukkan bahwa asupan vitamin C, Status Infeksi dan Status Gizi bukan merupakan faktor perancu sehingga analisis multivariate tidak perlu dilakukan.

\section{PEMBAHASAN}

Subyek penelitian ini sebanyak 50 anak dengan $\beta$ thalassemia mayor, pada kelompok perlakuan $88 \%$ pasien berusia lebih dari 5 tahun, dan hanya 3\% yang berusia kurang dari 5 tahun, sedangkan pada kelompok kontrol tidak ada perbedaan signifikan yaitu $76 \%$ pasien berusia lebih dari 5 tahun dan 24 persen berusia kurang dari 5 tahun. Sebuah penelitian dari Mannan A dkk pada

\begin{tabular}{|c|c|c|c|c|c|c|c|c|}
\hline \multicolumn{9}{|c|}{$\begin{array}{l}\text { TABEL } 1 \\
\text { Karakteristik demografis subjek }\end{array}$} \\
\hline \multirow[t]{2}{*}{ Variabel } & \multicolumn{2}{|c|}{ Kelompok I } & \multicolumn{2}{|c|}{ Kelompok II } & \multirow[t]{2}{*}{$p$} & \multirow[t]{2}{*}{ OR } & \multicolumn{2}{|c|}{ CI 95\% } \\
\hline & $n$ & $\%$ & $\mathbf{n}$ & $\%$ & & & Bawah & Atas \\
\hline \multicolumn{9}{|l|}{ Umur } \\
\hline$\leq 5$ tahun & 3 & 12,0 & 6 & 24,0 & $0,463^{1}$ & 0,432 & 0,095 & 1,966 \\
\hline$>5$ tahun & 22 & 88,0 & 19 & 76,0 & & & & \\
\hline \multicolumn{9}{|l|}{ Jenis kelamin } \\
\hline Laki-laki & 11 & 44,0 & 15 & 60,0 & $0,258^{2}$ & 0,254 & 0,170 & 1,612 \\
\hline Perempuan & 14 & 56,0 & 10 & 40,0 & & & & \\
\hline \multicolumn{9}{|l|}{ Status Gizi } \\
\hline Buruk & 5 & 20,0 & 4 & 16,0 & $0,926^{2}$ & & & \\
\hline Kurang & 11 & 44,0 & 12 & 48,0 & & & & \\
\hline Normal & 9 & 36,0 & 9 & 36,0 & & & & \\
\hline
\end{tabular}

Keterangan : ${ }^{1}$ Fisher's Exact Test, ${ }^{2}$ Pearson 


\begin{tabular}{|c|c|c|c|c|c|c|c|c|}
\hline \multicolumn{9}{|c|}{ Karakteristik manifestasi klinik Subyek } \\
\hline \multirow[t]{2}{*}{ Variabel } & \multicolumn{2}{|c|}{ Kelompok I } & \multicolumn{2}{|c|}{ Kelompok II } & \multirow[t]{2}{*}{$p$} & \multirow[t]{2}{*}{ OR } & \multicolumn{2}{|c|}{ CI 95\% } \\
\hline & $\mathbf{n}$ & $\%$ & $\mathbf{n}$ & $\%$ & & & Bawah & Atas \\
\hline \multicolumn{9}{|c|}{ Facies Coley } \\
\hline Ya & 17 & 68,0 & 16 & 64,0 & $0,675^{2}$ & 1,195 & 0,370 & 3,858 \\
\hline Tidak & 8 & 32,0 & 9 & 36,0 & & & & \\
\hline \multicolumn{9}{|l|}{ Pucat } \\
\hline Ya & 22 & 88,0 & 23 & 92,0 & $1,000^{1}$ & 0,638 & 0,097 & 4,188 \\
\hline Tidak & 3 & 12,0 & 2 & 8,0 & & & & \\
\hline \multicolumn{9}{|c|}{ Hepatomegali } \\
\hline Ya & 8 & 32,0 & 5 & 20,0 & $0,333^{2}$ & 0,1882 & 0,518 & 6,845 \\
\hline Tidak & 17 & 68,0 & 20 & 80,0 & & & & \\
\hline \multicolumn{9}{|c|}{ Pembesaran } \\
\hline Lien & 18 & 72,0 & 16 & 64,0 & $0,544^{2}$ & 1,446 & 0,438 & 4,781 \\
\hline Ya & 7 & 28,0 & 9 & 36,0 & & & & \\
\hline \multicolumn{9}{|l|}{ Tidak } \\
\hline \multicolumn{9}{|c|}{ Spelenektomi } \\
\hline Ya & 2 & 8,0 & 1 & 4,0 & $1,000^{1}$ & 2,087 & 0,177 & 24,615 \\
\hline Tidak & 23 & 92,0 & 24 & 96,0 & & & & \\
\hline
\end{tabular}

Keterangan : ${ }^{1}$ Fisher's Exact Test, ${ }^{2}$ Pearson

tahun 2013 mengenai pendekatan demografik dari pasien-pasien thalassemia termasuk pasien beta thalassemia mayor, didapatkan bahwa 100 persen pasien dengan bukti adanya beta thalassemia mayor, berusia kurang dari 10 tahun. Frekuensi yang tinggi pada usia lebih dari 5 tahun, terkait dengan mulai perlunya transfusi darah pada pasien thalassemia beta mayor. ${ }^{14}$

Moedrik Tamam dkk dalam penelitiannya mengenai hubungan mutasi gen dan manifestasi klinis pasien thallasemia, rerata umur pertama kali transfusi darah adalah 3,7 $\pm 3,01$ tahun, dengan rerata frekuensi transfusi adalah $6,67 \pm 5,41$ kali per tahun. Hal ini berarti untuk dapat mencapai lebih dari 20 kali transfusi, maka rata-rata usia anak sekitar 6,7 $\pm 6,01$ tahun atau di atas usia 5 tahun. ${ }^{15}$

Jenis kelamin baik dalam kelompok perlakuanmaupun dalam kelompok kontrol tidak terdapat perbedaan yang signifikan, dengan presentase terbanyak adalah perempuan. Hal ini berbeda dengan karakteristik demografi yang didapatkan oleh Mannan A dkk yang dilakukan di Bangladesh. Meski tidak terdapat perbedaan yang signifikan, namun pada region yang mereka teliti, laki-laki lebih banyak menderita beta thalassemia dibandingkan perempuan. ${ }^{14}$
Namun Moedrik Tamam dkk yang meneliti di regio yang sama dengan penelitian ini, meski tidak signifikan, mendapatkan karakteristik jenis kelamin yang sama pada pasien beta thalassemia yaitu wanita. ${ }^{15}$ Status gizi yang merupakan salah satu variabel perancu dalam penelitian ini, didapatkan perbedaan status gizi yang tidak signifikan di kedua kelompok. Status gizi terbanyak pada subjek penelitian adalah gizi kurang. $44 \%$ pada kelompok perlakuan dan $48 \%$ pada kelompok kontrol. Phurita Thongkijpreecha dkk, dalam penelitiannya terhadap status gizi pasien thalassemia intermedia mendapatkan bahwa status gizi terbanyak adalah malnutrisi sedang yaitu sebesar $40 \% .{ }^{16}$

Asupan makanan memegang peranan penting dalam menentukan status gizi pada pasien thalassemia. Dilaporkan bahwa pasien thalassemia membutuhkan lebih banyak asupan energi dibandingkan anak normal. Namun, Tanphaichitr dkk pada tahun 1995 menemukan bahwa justru asupan energi pasien thalassemia di negara berkembang rendah dan hanya mencukupi 65\% kebutuhan energi. ${ }^{17}$ Meskipun hasil dari pengukuran antropometri menandakan adanya gangguan pertumbuhan, namun sulit untuk disimpulkan bahwa penyebab dari malnutrisi pada pasien thalassemia akibat 


\begin{tabular}{|c|c|c|c|}
\hline \multicolumn{4}{|c|}{$\begin{array}{l}\text { KKadar Hb, Ht dan Fragilitas osmotik } \\
\text { Kelompok II (Kontrol) sebelum dan sesudah } \\
\text { perlakuan }\end{array}$} \\
\hline Variabel & Pre & Post & $p$ \\
\hline $\mathrm{Hb}$ & $5,84 \pm 1,287$ & $5,701 \pm 1,150$ & $0,591^{1}$ \\
\hline $\mathrm{Ht}$ & $18,25 \pm 4,011$ & $17,87 \pm 3,755$ & $0,798^{2}$ \\
\hline $\begin{array}{l}\text { Fragilitas } \\
\text { osmotik } \\
\text { eritrostik }\end{array}$ & $35,25 \pm 7,089$ & $29,15 \pm 9,043$ & $0,004^{1}$ \\
\hline
\end{tabular}

Keterangan : ${ }^{1}$ Paired t test,${ }^{2}$ Wilcoxon test

\begin{tabular}{|c|c|c|c|}
\hline \multicolumn{4}{|c|}{$\begin{array}{l}\text { Kadar Hb, Ht dan Fragilitas osmotik } \\
\text { Kelompok I (Perlakuan) sebelum dan sesudah } \\
\text { perlakuan }\end{array}$} \\
\hline Variabel & Pre & Post & $p$ \\
\hline $\mathrm{Hb}$ & $5,81 \pm 1,032$ & $6,65 \pm 0,741$ & $0,000^{1}$ \\
\hline $\mathrm{Ht}$ & $17,96 \pm 2,855$ & $20,12 \pm 2,404$ & $0,001^{2}$ \\
\hline $\begin{array}{l}\text { Fragilitas } \\
\text { osmotik } \\
\text { eritrostik }\end{array}$ & $30,75 \pm 5,685$ & $38,19 \pm 6,977$ & $0,000^{1}$ \\
\hline
\end{tabular}

Keterangan : ${ }^{1}$ Paired t test, ${ }^{2}$ Wilcoxon test

\section{TABEL 6}

Selisih $\mathbf{H b}$, Ht dan Fragilitas osmotik pada dua kelompok

\begin{tabular}{lccc} 
Variabel & Kelompok I & Kelompok II & $\boldsymbol{p}$ \\
\hline Selisih Hb & $0,83 \pm 0,743$ & $-0,13 \pm 1,216$ & $0,001^{1}$ \\
Selisih Ht & $2,13+2,788$ & $-0,38 \pm 3,877$ & $0,012^{1}$ \\
Selisih Fragilitas osmotik & $7,44+5,729$ & $-6,10 \pm 9,467$ & $0,000^{2}$ \\
\hline
\end{tabular}

Keterangan : ${ }^{1}$ Independent $\mathrm{t}$ test, ${ }^{2}$ Mann Whitney test

dari asupan yang kurang. Beberapa faktor dapat menjadi penyebab, seperti eritropoesis yang tidak efektif sehingga terjadi anemia yang kronis, hiperkatabolik, dan disfungsi hormonal. ${ }^{18}$

Karakteristik manifestasi klinis pada kedua kelompok perlakuan dan kontrol, tidak didapatkan perbedaan yang bermakna. Didapatkan splenomegali $72 \%$ pada kelompok perlakuan dan $64 \%$ pada kelompok kontrol. Limpa yang besar merupakan wadah pool dari darah sehingga akan lebih mudah mengalami destruksi dan menambah volume plasma sehingga kebutuhan akan transfusi darah akan cenderung meningkat. Indikasi splenektomi ialah limpa yang terlalu besar sehingga membatasi gerak penderita sehingga menimbulkan peningkatan tekanan intraabdominal dan bahaya terjadinya ruptur, hipersplenisme ditandai dengan peningkatan kebutuhan transfusi darah atau kebutuhan suspensi eritrosit/Packed Red Cell/PRC melebihi $250 \mathrm{mg} / \mathrm{kgbb}$ dalam satu tahun. Didapatkan 3 subjek yang telah dilakukan splenektomi, yaitu 2 pada kelompok perlakuan dan 1 pada kelompok kontrol.

Kadar Hemoglobin sebelum perlakuan pada kelompok perlakuan adalah 5,81 \pm 1,032 dan pada kelompok kontrol 5,84 $\pm 1,287$. Syed Riaz Mehdi dkk yang meneliti status hemoglobin pasien thalasemia mengatakan bahwa pada usia 7-13 tahun, kadar $\mathrm{Hb}$ antara 7-13 memiliki porsi terbesar, disusul dengan $\mathrm{Hb}$ di bawah 7. Semakin bertambah umur pasien, semakin rendah kadar hemoglobin pasien akibat dari semakin besarnya stres oksidatif yang kemudian semakin memperburuk fragilitas osmotik pasien, sehingga pecahnya sel darah merah semakin cepat. ${ }^{19}$

Terdapat kenaikan yang signifikan dari fragilitas osmotik eritrosit ke arah rentang normal pada kelompok perlakuan yang mendapat vitamin C $100 \mathrm{mg}$ per hari. Ikatan silang dari membran eritrosit menjadi lebih kaku pada pasien thalassemia dibandingkan dengan normal. Setelah pemberian vitamin C $100 \mathrm{mg}$ per hari selama 6 bulan dan 12 bulan, pasien dengan $\beta$ thalassemia major memberikan peningkatan yang signifikan terhadap parameter nonenzimatik dibandingkan sebelum diberikan terapi. Namun parameter tersebut tidak dapat menjadi normal akibat besarnya stres oksidatif yang terjadi pada pasien thalassemia mayor. ${ }^{12}$ Hal ini sesuai dengan penelitian Thasinas et al. Yang menyimpulkan bahwa, setelah pemberian 3 bulan vitamin $C$ dan vitamin E, memberikan peningkatan namun tidak dapat menormalkan. Pada penelitian ini, diberikan vitamin $\mathrm{C}$ selama 1 bulan dengan dosis $100 \mathrm{mg}$ per hari, dan didapatkan pada kelompok perlakuan peningkatan fragilitas osmotik yang signifikan, namun tidak dapat hingga menormalkan. Pada kelompok kontrol yang 


\begin{tabular}{|c|c|c|c|c|c|c|c|c|}
\hline $\begin{array}{l}T A B E L 6 \\
\text { Faktor pera }\end{array}$ & & & & & & & & \\
\hline \multirow[t]{2}{*}{ Variabel } & \multicolumn{2}{|c|}{ Kelompok I } & \multicolumn{2}{|c|}{ Kelompok II } & \multirow[t]{2}{*}{$p$} & \multirow[t]{2}{*}{ OR } & \multicolumn{2}{|c|}{ CI 95\% } \\
\hline & $\mathbf{n}$ & $\%$ & $\mathbf{n}$ & $\%$ & & & Bawah & Atas \\
\hline \multicolumn{9}{|c|}{ Asupan vitamin C } \\
\hline Kurang & 16 & 64,0 & 16 & 64,0 & $1,000^{2}$ & 1,000 & 0,315 & 3,174 \\
\hline Tidak & 9 & 36,0 & 9 & 36,0 & & & & \\
\hline \multicolumn{9}{|l|}{ Status infeksi } \\
\hline Ya & 3 & 12,0 & 1 & 4,0 & $0,609^{1}$ & 3,273 & 0,317 & 33,837 \\
\hline Tidak & 22 & 88,0 & 24 & 960,0 & & & & \\
\hline \multicolumn{9}{|l|}{ Status Gizi } \\
\hline Buruk & 16 & 20,0 & 4 & 16,0 & $0,926^{2}$ & & & \\
\hline Kurang & 11 & 44,0 & 12 & 48,0 & & & & \\
\hline Normal & 9 & 36,0 & 9 & 36,0 & & & & \\
\hline
\end{tabular}

Keterangan : ${ }^{1}$ Fisher's Exact Test, ${ }^{2}$ Pearson Chi Square

diberikan placebo, terdapat penurunan fragilitas osmotik eritrosit yang signifikan. Peningkatan fragilitas osmotik eritrosit, yang merupakan bukti dari berkurangnya akibat dari stres oksidatif pada membran sel eritrosit, kemudian akan meningkatkan kadar $\mathrm{Hb}$ oleh karena pecahnya eritrosit yang melewati kapiler akibat kekakuan membran eritrosit menjadi menurun dan meningkatkan $\mathrm{Hb}$. Pada kelompok perlakuan terjadi kenaikan hemoglobin yang signifikan, sedangkan pada kelompok kontrol didapatkan penurunan hemoglobin namun tidak signifikan. ${ }^{20}$

Penelitian yang dilakukan tentang efek vitamin antioksidan pada Hemoglobin dan eritrosit pada Beta thalassemia homozgot menyebutkan bahwa pasien diberikan vitamin E, C dan A selama 12 bulan. Nilai rerata hemolisis pada anak $\beta$ thalassemia mayor sebelum pengobatan lebih nilai dari kelompok kontrol, sedangkan anak dengan $\beta$ thalassemia mayor sesudah pengobatan lebih rendah dari sebelum pengobatan. Hasil dari analisis spekrtrofotometrik multikomponen menunjukkan hasil terjadi penurunan prosentase Met $\mathrm{Hb}$ dan $\mathrm{HbCO}$ bersamaan dengan kenaikan bermakna prosentase HB O2 pada darah penderita $\beta$ thalassemia sesudah pengobatan dengan vitamin antioksidan, bila dibanding dengan sebelum pengobatan. Hasil akhir penelitian tersebut adalah bahwa pengobatan pasien $\beta$ thalassemia dengan vitamin antioksidan mengurangi hemolisis sel darah merah dan meningkatkan kadar $\mathrm{Hb}$ penderita. $\mathrm{Di}$ samping itu juga pemberian vitamin antioksidan menurunkan kadar $\mathrm{Hb}$ inaktip ( $\mathrm{HbCO}$ and $\mathrm{Met} \mathrm{Hb}$ ) dan meningkatkan konsentrasi $\mathrm{Hb}$ aktip ( $\mathrm{HbO} 2)$ dan tidak ada pengaruh terhadap rerata denaturasi alkalin $\mathrm{Hb}^{12}$
Keterbatasan dalam penelitian ini tidak melakukan pemeriksaan kadar vitamin C sebelum dan sesudah perlakuan.

\section{SIMPULAN}

Pemberian vitamin $\mathrm{C}$ dapat memperbaiki fragilitas osmotik eritrosit pada pasien $\beta$ thalassemia selama 1 bulan. Disarankan pemberian vitamin $C$ pada pasien $\beta$ thalassemia mayor sebaiknya diberikan lebih dari 1 bulan dengan dosis yang ditambah.

\section{DAFTAR PUSTAKA}

1. Cao A, Galanello R. Beta-thalassemia. Genetics in medicine : official journal of the American College of Medical Genetics. 2010;12(2):61-76. Epub 2010/01/26.

2. Kattamis C, Efremov G, Pootrakul S. Effectiveness of one tube osmotic fragility screening in detecting b-thalassaemia trait. J Med Genet 1981;18:266-70

3. Sankaran VG, Nathan DG. Thalassemia: an overview of 50 years of clinical research. Hematology/oncology clinics of North America. 2010;24(6):1005-20. Epub 2010/11/16.

4. Cappellini MD, Bejaoui M, Agaoglu L, Canatan D, Capra M, Cohen $\mathrm{A}$, et al. Iron chelation with deferasirox in adult and pediatric patients with thalassemia major: efficacy and safety during 5 years' follow-up. Blood. 2011;118(4):884-93. Epub 2011/06/02.

5. Cakmak A, Soker M, Koc A, Aksoy N. Prolidase activity and oxidative status in patients with thalassemia major. Journal of clinical laboratory analysis. 2010;24(1):6-11. Epub 2010/01/21

6. Fibach E, Rachmilewitz EA. The role of antioxidants and iron chelators in the treatment of oxidative stress in thalassemia. Annals of the New York Academy of Sciences. 2010;1202:10-6. Epub 2010/08/18. 
7. Vasileiadis I, Roditis P, Dimopoulos S, Ladis V, Pangalis G, Aessopos A, et al. Impaired oxygen kinetics in betathalassaemia major patients. Acta Physiol (Oxf). 2009;196(3):357-63. Epub 2008/12/02.

8. Levine M, Conry-Cantilena C, Wang Y, Welch RW, Washko PW, Dhariwal KR, et al. Vitamin C pharmacokinetics in healthy volunteers: evidence for a recommended dietary allowance. Proceedings of the National Academy of Sciences of the United States of America. 1996;93(8):3704-9. Epub 1996/04/16.

9. Schorah CJ, Downing C, Piripitsi A, Gallivan L, Al-Hazaa AH, Sanderson MJ, et al. Total vitamin C, ascorbic acid, and dehydroascorbic acid concentrations in plasma of critically ill patients. American J Clin Nutr. 1996;63(5):760-5. Epub 1996/05/01

11. Dissayabutra T, Tosukhowong P, Seksan P. The benefits of vitamin $C$ and vitamin $E$ in children with beta-thalassemia with high oxidative stress. Journal of the Medical Association of Thailand = Chotmaihet thangphaet. 2005;88 Suppl 4:S317-21. Epub 2006/04/21.

12. Attia MMA,. Sayed AM, Ibrahim FA Mohammed AS, ELAlfy MS. .Effect of Antioxidant vitamins on some Hemoglobin properties and erythrocytes in homozygous Beta thalassemia . Romanian J. Biophys : $2011 ;(21), 1: 116$.

13. Khalid U. Osmotic Fragility of Erythrocytes. Medscpae referrence. (Internet) (Cited September 22, 2013). Available in : http://emedicine.medscape.com/article/2085814-overview.

14. A. Mannan, J. Kawser, A.M.A. Ahmed, Mohd. Omar Faruk Sikder, M.J. Islam and M.A. Chowdhury, 2013. A Demographic Approach for Understanding the Prevalence of $\beta$ Thalassemia Patterns and Other Hemoglobinopathies: Selective Study in Chittagong City Perspective. Asian Journal of Biological Sciences, 6:124-130.
15. Tamam M, Hadisaputro S, Sutaryo S, Setianingsih I, Astuti R, Soemantri Ag. Hubungan antara tipe mutasi gen globin dan manifestasi klinis penderita talasemia. Jurnal Kedokteran Brawijaya, Vol. 26, Februari 2010.

16. Thongkijpreecha P, Kangsadalampai O, Pongtanakul B, Meksawan K. Nutritional Status in Patients with Thalassemia Intermedia. Journal of Hematology and Transfusion Medicine. July-September 2011;21:3.

17. Tanphaichitr V, Visuthi B, Tanphaichitr V. Causes of inadequate protein-energy status in thalassemic children. Asia Pacific J Clin Nutr 1995;4:133-5.

18. Soliman AT, El-Matary W, Fattah MMA, et al. The effect of highcalorie diet on nutritional parameters of children with $\beta$ thalassaemia major. Clin Nutr 2004;23:1153-8.

19. Mehdi SR, Dahmash BAA. A comparative study of hematological parameters of $\alpha$ and $\beta$ thalassemias in a high prevalence zone: Saudi Arabia. Indian J Hum Genet. 2011 Sep-Dec; 17(3): 207-211.

20. Thasina D.,Piyaratna T, Panya S, The benefits of vitamin C and vitamin $\mathrm{E}$ in children with $\mathrm{B}$-thalassemia with high oxidative stress, J. Med. Assoc. Thai., 2005, 88, 48. 